\title{
Competitiveness in Michoacán: A Proposal for an International Positions in Agroindustrial Sector
}

\author{
Odette V. Delfin-Ortega ${ }^{1}$ \& Joel Bonales Valencia ${ }^{1}$ \\ ${ }^{1}$ Institute of Economic Research and Enterprise from Universidad Michoacana de San Nicolás de Hidalgo Morelia, \\ Michoacán, México
}

Correspondence: Odette V. Delfin-Ortega, Institute of Economic Research and Enterprise, Universidad Michoacana de San Nicolas de Hidalgo, Morelia. Mich., México. Tel: 52-443-316-5131. E-mail: odettedelfin@hotmail.com

Received: November 5, 2014 Accepted: December 5, 2014 Online Published: January 15, 2015

doi:10.5539/jas.v7n2p106 URL: http://dx.doi.org/10.5539/jas.v7n2p106

\begin{abstract}
The present research has as aim, to determine the ways in which are affected the quality, the price, the technological innovation, the environmental management, the market and the public agro industrial policies in the international competitiveness of the agro industrial sector of Michoacan. It was located 51 agroindustrial companies that are exporting. It was used as instrument of compilation of information a questionnaire composed of 80 items. Once the information was processed, it was determined the correlational analysis, linear regression and attempts at hypothesis. We can see with the results that the state is competitive in this sector and that the variables explain $97 \%$ of the competitiveness. The variable that determined the competitiveness with greater proportion was the technological innovation, so it requires public policies that strengthen this indicator and the sector can be even more competitive. In the other hand public polices in agro business got the lowest score and there is a gap in the implementation of programs and modernization in the sector that causes both nationally and internationally doesn't be strong in the area of agribusiness Michoacan, so it must strengthen these policies from the national development plan.
\end{abstract}

Keywords: competitiviness, agroindustrial, Michoacan

\section{Introduction}

Agriculture is a vulnerable sector in Mexico and therefore in Michoacan state, so its development represents an economic and social balance. To the extent that quality, price, technological innovation, environmental management, market and public policy impact on the competitive development of the state; agribusiness firms will be more profitable and the industry is constantly growing. International markets every day become more demanding and regulations coupled with quality are a challenge for local supply (Padilla et al., 2010; Carvalho \& Santos, 2006). Competitiveness is essential for economic growth. Productivity growth is a major element of sustained competitiveness and is largely linked to the adoption of new technologies or other innovations (Toming, 2010; OECD, 2011).

Market forces directly influence in export supply and the agricultural sector is one such example through technological development and has been able to improve their different phases of production and industrialization (Ball et al., 2006; Latruffe, 2010). Food and Agriculture Organization (FAO) says that "the industrialization of agriculture and agribusiness development is a common process that is creating an entirely new type of industrial sector" (FAO, 2014).

Michoacan State is the largest producers of fruits in the country with a production of 2 million tons per year (SAGARPA, 2009). But agribusiness has not developed in the same direction and we can see that Michoacan ranks 18 place with respect all the country, so it has to direct the attention to improve the development and encourage greater competitiveness (Agrointernet, 2009); aimed not only at national but also international markets. Therefore, this research has as main objective to determine how affect the quality, price, technological innovation, environmental management, market and public policies on the competitiveness of the agribusiness sector in Michoacan State. The results obtained can be used for decision making in the private and government sector (Pallares, 1998); therefore government programs will be aimed in that direction. This leads to increased business in the industrialized agricultural products in order to strengthen the sector (López \& Castrillón, 2007). 
The hypothesis is that "The quality, price, technological innovation, environmental management, market and agro-industrial policies are the main causes of the agribusiness exports of Michoacan state have increased international competitiveness".

\section{Methods}

The study of foreign trade has been initiated on the theoretical framework of the economy explained by Adam Smith, David Ricardo and John Stuart Mill. Even as the economic, political and social environment in which the current classical studies arise are very different from the reality of our days, the analysis of the classical approach is the foundation for understanding the theory and logic of post developments in international trade theory. This theory emerges as the liberal response to mercantilist restrictions against free trade, since its inception Smith shows that a small difference in cost may be enough to benefit from the exchange between countries; Ricardo Smith reinforces the idea of considering the absolute advantage as a special case of a less stringent notion, such as comparative advantage, to reaffirm the benefits of trade (Ricardo, 1971).

Ricardo and Mill idea is that international trade will result in a complete specialization in the production of goods in which they have comparative advantage from the others with some products. For agribusiness Michoacan, an agricultural state, has a specialization in the fruit and vegetable and it has a comparative advantage over other states of the republic; therefore at the time of trade between countries will get more profit if the exported products are more competitive than other countries that send the same or similar products (Dini, 2010).

Michael Porter is an author in which this research is based; considering as a starting point his "Competitive Advantage" (Porter, 2007) and assigning the value that a company is able to create for its applicants; as lower than those of its competitors or the equivalent provision of differentiated products, where income benefits outweigh the costs prices. In its brief states that the value is the amount that buyers are willing to pay for what the company provides. Then a company is profitable if the value that it gets from its sales is greater than its cost of production. The goal of every business is to create products where the value is greater than its costs. To analyze this process, he used what he called "value chain" or a series of activities from which arises a value.

Furthermore competitive strategy Michael Porter is the way that a company has to compete; through which the company objectives are developed and it is trying to achieve in a market; taking into account the policies needed to achieve them. So the competition is a benchmark which can lead us to success or failure, so for strategy, it is important that the company is related to its environment (Fernández, 2005).

\subsection{Methodology}

This research seeks to measure competitiveness for that, in a first step, a questionnaire is used as a tool to obtain the primary information sources. We obtained the variables from literature review, obtaining as a result the following variables:

Dependent Variable: competitiveness;

Independent Variables: quality, technological innovation, environmental management, price, market and public policy;

Universe: Currently there are 18,119 companies in Michoacán established in the Registration of Business Information System of Mexico; of which only 345 firms export;

Population: The population was obtained from the following sources: Business Information System of Mexico through the Ministry of Economy; Cexporta and Customs Broker Barrenechea. We obtained 51 export agribusiness companies in the perishable area in Michoacan state.

The Likert Scale was used for processing data with SPSS; this scale is a very useful tool as it is designed to measure attitudes. From the arithmetical point of view it is a summation scale and the score or measure of each person in the attitude in question is given by the sum of their responses to questions that was implemented.

For this study we work with 80 items, which were reviewed in detail and were developed according to each study variable.

It can get different kind of score for each variable between the maximum and minimum values as shown in the Table 1: 
Table 1. Response values

\begin{tabular}{lll}
\hline Variable & Minimum value & Maximum value \\
\hline Quality & 10 & 50 \\
Technological innovation & 14 & 70 \\
Environmental management & 15 & 75 \\
Price & 10 & 50 \\
Market & 16 & 80 \\
Agribusiness Public Policy & 15 & 75 \\
Competitiveness & 80 & 400 \\
\hline
\end{tabular}

Source: Own calculations based on the results of likert scale.

The next step was to verify the reliability of the instrument with Cronbach Alpha technic; where the following formula was used:

$$
\propto=\frac{\kappa}{\kappa-1}\left(1-\mid \frac{\Sigma \delta_{i}^{2}}{\delta_{x}^{2}}\right)
$$

Where:

$\mathrm{K}$ : is the number of the items; $\sum \mathcal{S}_{i}^{2}$ : Is the sum of the variance of the items; $\delta_{x}^{2}$ : It is the variance of the total score.

The survey results were processed using SPSS; giving as result:

Table 2. Cronbach's alpha result

\begin{tabular}{ll}
\hline Reliability & \\
\hline Cronbach's Alpha & No. of Items \\
0.951 & 80 \\
\hline
\end{tabular}

Source: Results obtained on base SPSS.

This means that the degree of reliability of the test is high.

\subsection{Quantitative Analysis Techniques}

Once registered the information, it continues with the process of analysis and interpretation of data. The importance of them is that they are useful for organizing, describing and analyzing the data collected by the instruments of investigation tools. To test the hypothesis the ordinary least squares (OLS) method is used.

The basics of traditional econometrics and time series are composed of mathematical and statistical methods to estimate the dependence of an endogenous variable of other exogenous variable and quantification or association that may exist between them. Therefore application allows express and economic measures, and enables an economic theory expressed in mathematical form (single equation or multi-equation models), and verify statistical indicators (hypothesis testing) (Loria, 2007).

Within the mathematical methods applied to economics and business highlights the least squares under it with him to do regression analysis and correlation, both simple and multiple.

With the regression analysis, it can determine the dependence of a variable $(Y)$ of another variable $(X)$ when it is a single regression or several variables $(X, Z, Q)$ when it is a multiple regression. In the first, $Y$, is called the dependent variable (also called endogenous, explained or returned); the second, $(X)$, is known as an independent variable, explanatory, exogenous or regressor. With the correlation analysis, the relation, the association or degree in which $X$ explains $Y$.

The dependence of $X$ of $Y$ is expressed mathematically as follows: $Y=f(X)$ and is called functional. The mathematical development and especially its application in computer currently available to the researcher many functional forms for regression analysis and correlation. Among the best known is that of the straight, the 
parabola, exponential, hyperbola, reciprocal, etc. (Loria, 2007).

The equation describing this model is:

$$
Y_{t}=\beta_{0}+\beta_{1} X_{1 t}+\cdots+\beta_{i} X_{i t}+\beta_{k} X_{k t}+\varepsilon_{t} \quad(\mathrm{~T}=1, \ldots \mathrm{T})
$$

The $Y_{t}$ variable is the dependent or endogenous variable, $X_{i t, i}, \mathrm{i}=1, \ldots \mathrm{K}$ are the explanatory variables and $\varepsilon_{t}$ is the random disturbance, $c(\mathrm{~K}+1)$ are the parameters associated with each of explanatory variables called the regression coefficient and measures the impact of each variable on the behavior of the endogenous variable. $\beta_{0}$ is the independent term and may be said to be the parameter associated with an explanatory variable that takes the value 1 for all observations and therefore does not appear explicitly in the equation.

The statistic test used for this hypothesis is the statistical " $t$ " is calculated as the ratio estimator and its standard error and allows the hypothesis that the coefficient is equal to zero $\left(\mathrm{H}_{0:} \beta_{i}=0\right.$ and $\left.H_{1}: \beta_{i} \neq 0\right)$ and therefore, determine whether the variable is individually significant to the dependent variable (Carrascal, González, \& Rodriguez, 2001).

Now the method of least squares (Carrascal et al., 2001) is based on the fulfillment of the following assumptions or classical assumptions:

1. Implicit in the specification of the model equation is the linearity of the relationship and the constancy of the parameters.

2. There are no exact linear relationships among the explanatory variables or regressors, besides that these are not random variables.

3. There exact linearity between variables only when the independent variable is raised to the pwer of 1 (Gujarati, 1990) and $x 2$ terms are excluded, among others. Of the two interpretations of the parameters linearity is the most important in the theory and regression means that the parameters are increased to the first power.

4. The random disturbances are variable (random or stochastic) independent and equally distributed normal with zero mean and some variance.

5. There is no autocorrelation (they are independent) to each random perturbations Ui.

6. All random perturbations have equal variance, in other words, there is homoscedasticity, the Ui.

7. There zero covariance (COV) between the explanatory variable (Xi) and the variable or random disturbance (Ui), in other words, uncorrelated so that their significance in the dependent variable (Yi) is separated and additive. When $\mathrm{X}$ and $\mathrm{Ui}$ are correlated (positively or negatively) is difficult to isolate the individual influence of $\mathrm{Xi}$ and Yi Ui.

On the significance observed in these cases where the correlation involved, it must be said that the quantification of the relationship between $Y$ and $X$, regardless of whether they are qualitative or quantitative variables is done with statistics like the correlation coefficient $\mathrm{R}$, the determination $\mathrm{R} 2$ and adjusted determination.

It is said that when $\mathrm{R}$ tends to one, there is a strong relationship or correlation between $X$ and $Y$, such that $X$ is a good explanatory variable $Y$. That is, we can explain the behavior of $Y$ based on the behavior of $X$. In this case if $X$ increases, $Y$ also does.

\section{Results}

This research is based on the assumption that the dependent variable competitiveness is impacted by independent variables: quality, technological innovation, environmental management, pricing, market and public policy. The questionnaire consists of 80 items that include variables, indicators and dimensions, and together account for international competitiveness. The responses were weighted according to the Likert Scale (Fernandez, 2005), representing a very low competitiveness with value 1 and highly competitive with the value 5 . It was begun with the dependent variable "International competitiveness", in Table 3 the results are observed 
Table 3. Competitiviness descriptive statistics

\begin{tabular}{ll}
\hline Index & Value \\
\hline Mean & 273.01 \\
Median & 274 \\
Mode & 268 \\
Standard Deviation & 18.42 \\
Variance & 339.49 \\
Asymmetry & -0.899 \\
Kurtosis & 1.161 \\
Range & 86 \\
Minimum & 217 \\
Maximum & 303 \\
Sum & 13924 \\
\hline
\end{tabular}

Source: Based on data from field study.

Table 3 shows the values obtained from measurements of central trend and dispersion; the average is 273.01 and very close to this value is the median that had a value of 274 which is also located in the competitive range, however, the mode is located between two values: one is 268 (which is located in the box Regular competitiveness) and the other is 275 (which is in the competitive range). Standard deviation indicates how the values are far from the mean; in this case is 18.42 . The distance is as follows: from the middle to both sides: $(273.01+18.42)$ and $(273.01-18.42)$ being the results from: 291.43 and 254.59 and is where the highest percentage of response was observed with a $80.39 \%$; addition to the value obtained is 18.42 less than the value 64, which is the distance between each of the Likert response scale processed.

Furthermore the asymmetry coefficient indicates that if $(\mathrm{g} 1>0)$ the curve is asymmetrically with negative values tend to gather more on the right side of the mean that is what happens in this case because it gave a result the value of -0899. Kurtosis determine the degree of concentration values presented in the central region of the distribution. In this case the result is 1.161 coefficient value is greater than "zero" (g2 >0) so that in this case the distribution is leptokurtic.

The frequency distribution of the minimum response value was 217 and 303 having a maximum distance between them of 86 points; the values were below the mean, representing $45.09 \%$ of total values. The rest of the results, 54.91\%, are the average upward, reaching the competitive picture. Therefore the overall result agribusiness export of Michoacan, according to the Likert scale is considered "competitive" as shown below:

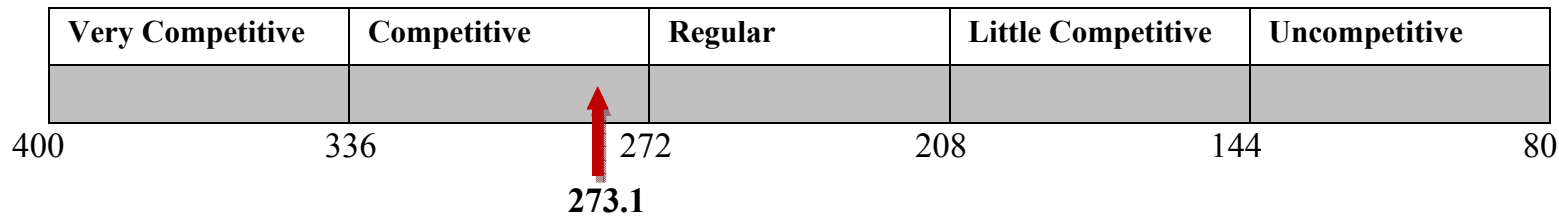

\subsection{Hypothesis Testing}

To test hypotheses presented below so bivariate dependent variable "competitiveness" with each of the independent variables, the method used Least squares with Eviews program as shown in Table 4.

Dependent Variable: Competitiviness;

Method: Least Squares;

Sample: 1 51;

Included observations: 51 . 
Table 4. Agro-business competitiviness in Michoacan

\begin{tabular}{lllll}
\hline Variable & Coefficient & Std. Error & t-Statistic & Prob. \\
\hline C & 0.618352 & 1.642228 & 0.376532 & 0.7083 \\
Quality & 0.118593 & 0.031893 & 3.718445 & 0.0006 \\
Environmental management & 0.176276 & 0.018131 & 9.722264 & 0.0000 \\
Technological innovation & 0.188143 & 0.021742 & 8.653331 & 0.0000 \\
Market & 0.153997 & 0.013658 & 11.27553 & 0.0000 \\
Agribusiness Public Policy & 0.153409 & 0.018187 & 8.435290 & 0.0000 \\
Price & 0.173260 & 0.029797 & 5.814588 & 0.0000 \\
\hline R-squared & 0.971360 & Mean dependentvar & & 45.05882 \\
Adjusted R-squared & 0.967454 & S.D. dependentvar & & 3.081634 \\
S.E. of regression & 0.555940 & Akaikeinfocriterion & & 1.790561 \\
Sum squaredresid & 13.59905 & Schwarzcriterion & & 2.055714 \\
Log likelihood & -38.65931 & Hannan-Quinncriter. & & 1.891884 \\
F-statistic & 248.7168 & Durbin-Watson stat & & 2.369547 \\
Prob(F-statistic) & 0.000000 & & & \\
\hline
\end{tabular}

Source: Own calculations based on the results of the eviews program.

After running the model results are analyzed and the null hypothesis is rejected, because applying the $t$ test, it is found that the values obtained $\neq 0\left(H_{1}: \beta_{i} \neq 0\right)$ and the probability $\mathrm{p}<0.05, \mathrm{p}=0.0000$ being so there is enough statistical evidence to reject the null hypothesis H0, accepting the alternative hypothesis H1. However it is observed that the result is 0.97 square $\mathrm{R}$ by indicating that the variables explain $97 \%$ of the dependent variable competitiveness. Therefore the hypothesis is adopted based on the data presented.

The coefficient shown indicates the change that the endogenous variable (Y1); to a unit change in the explanatory variable (X1) while all other variables remain constant; this way if the quality increases one unit, competitiveness increases 0.11 units, in the case of environmental management increased by 0.17 , with technological innovation increases 0.18 ; in the case of market and public policy increases 0.15 .

\section{Discussion}

This research was conducted in the agro-export sector in which we sought to measure competitiveness at sector and subsector for each processed product export, as the competitiveness of a product depends on the constituent companies and their capacity to produce goods that meet the requirements of buyers, in addition to its ability to capture markets. This measurement helps to identify the factors that contribute to strengthening or weakening the competitiveness of agri-business industry.

The results of the data processing show a picture of how it is agro export sector in the state. The results of the Likert scale shows that the industry is competitive. Indeed the first instance Michoacan has fresh fruits and vegetables with a strong position in international markets that give direct entry into processed products online; however trends are focused markets increasingly demand products such as pasta, juices and purees, as was observed in this investigation, it is unfortunate there are small number of companies exporting processed products in this case were counted 51; and that results that are not adding value to exports of agricultural products from Michoacan as there are many crops that can be harvested. Also it is found in low numbers industrialization of the sector, since in 2012 the share of the primary sector was $24,607.5$ million pesos vs 4171.6 million pesos in agribusiness.

Michael Porter theory was the fundamental part in achieving competitive advantage which is based on the technological and human capacity to produce more. It is observed in this research that technological innovation variable has a high correlation with competitiveness and more companies where implemented this factor in their enterprises, in order to have a higher competitive values. In other hand the profitability of exports of agro products is one of the objectives of the companies, however there are external factors that are not always possible to reach, these results as in the case of high input costs, speculation price target markets, non-tariff 
barriers that require changes in processes and procedures which require capital investments and available to meet them.

Michael Porter mentioned four factors that may be determinants of competitiveness: the introduction of a new product or an existing differentiation; the introduction of a new production process, opening new markets, changes in industrial organization. However in Michoacan it is not easy to implement because the companies don't have money to develop these strategies so the government need to implement agro industries policies because the exporters require capital, training, access to research and technology, and the only way they can get them is through government programs.

Several studies have been conducted on measuring competitiveness as presented below:

Wijnands, Bremmers, van der Meulen, and Poppe (2008) made a measurement of competitiveness of food industry of Australia, Brazil, Canada, and the United States in 1996-2004. They used trade data of world market. The results showed that United States less level of competitiviness than Brazil. In this research, we made the analysis of Mexico and one of the variables were market and opposite occurred with Wijnands et al., this one was the most representative variable for the competitiveness in which we obtained the highest score.

Other research was made by Bojnec and Fertö (2009), who realized a measurement of international competitiviness of agribusiness sector in eight countries: Bulgaria, Croatia, Czech Republic, Hungry, Poland, Rumania, Slovakia, Slovenia in 1995-2007. They used trade data using four products: raw commodities, processed intermediates, horticulture and consumer-ready food. The results showed that raw commodities had export competitive advantage for all countries. In this research one of the products that was assessed, was the horticulture and like this research, this subsector was not as representative, specifically in our case was most impressive fruit sector.

Qineti, Rajcaniova, and Matejkova (2009) made a research where computed the competitiveness of agrifrut sector of Slovak, United States, Russia and Ukraine in the period 2002-2006. The main conclusions were that commodity group had comparative advantage in the United States and opposite occurred with Russia and Ukraine which had declined in this group. In this research we got competitiveness index like these authors and we observed that in the state there is a high level of competitiveness; however it was not included in the study a commodity sector just fruit and horticulture sectors.

Finally Van Berkum (2009) realized a competitiveness study of agrobusiness products exported of several european countries. He concluyed the Baltic countries and Poland had increased their export surpluses since the 1990s. In our research, the factor of export of agro products was key to measuring competitiveness and its position in the international markets as well as the study of these authors and it was increasing through the years like this research.

\section{Conclusions}

Michoacan currently requires a big push to grow as a state and be more competitive, the agricultural sector has been a central axis within the same economic boost, particularly in fruit and vegetable products, which is much currently positioned in international markets. The industrialization of agricultural products is a fundamental part of economic and social developments.

To determine the competitiveness of the agribusiness sector of Michoacan, it was used a questionnaire with 80 items and it was processed through the Likert scale, in order to obtain the degree of competitiveness. In a second stage the OLS technique was applied to test the hypothesis.

Furthermore, the results of the questionnaire using the Likert scale was observed that the agribusiness sector of Michoacan is competitive, since an average of 273 points being in the competitive range was obtained

The hypothesis presented at the beginning, was confirmed because the results obtained from the least squares technique showed that quality, technological innovation, environmental management, price, market and public policy determine international competitiveness of the agribusiness sector. Since the results obtained in the coefficient of determination $\mathrm{r}^{2}$ was 0.97 .

The variable that determined the competitiveness with greater proportion was the variable technological innovation, so they require public policies that strengthen this indicator and the sector can be even more competitive. There is a gap in the implementation of programs and modernization in the sector that causes both nationally and internationally, Michoacán isn't strong in the area of agribusiness only fresh products.

The government through agricultural policies, boosted production chains with the creation of the product system however although the purpose was to strengthen each link in the chain, strengthening occurs only at producing 
fresh, making reflect on the importance of resource programs that strengthen each of the activities specifically in promoting income new markets with higher levels of requirement on par with higher value-added products are developed.

\section{References}

Agrointernet.

(2009). Agronegocios-analisis

Económicos. Retreived

from http://www.agrointernet.com/index.php/agronegocios/240-agronegocios-analisis-economico-.html

Ball, E., Butault, J. P., San Juan, M. C., \& Mora, R. (2006). Productivity and International Competitiveness of European Union and United States Agriculture, 1973-2002. Paper presented at the AIEA2 International Meeting Competitiveness in agriculture and the food industry: United States and EU perspectives, Bologna.

Bojnec, S., \& Latruffe, L. (2009). Determinants of technical efficiency of Slovenian farms. Post-Communist Economies, 21(1), 117-124. http://dx.doi.org/10.1080/14631370802663737

Carvalho, L., \& Santos, R. (2006). Estudios sociedade de agricultura. Programa de Apoio a núcleos de excelencia. Brasil: Nucleo de Estudos Agrários e desenvolvimento.

Carrascal, A. U., González, Y., \& Rodríguez, B. (2001). Análisis Econométrico con Eviews. RA-MA editorial. Madrid

Dini, M. (2010). Competitividad, redes de empresas y cooperación empresarial (72nd ed.). Santiago, Chile: Series CEPAL.

Food and Agriculture Organization of the United Nations (FAO). (2014). Perspectivas de la agricultura y del desarrollo rural en las Américas: una mirada hacia América Latina y el Caribe 2014. Retreived from http://www.fao.org/publications/card/es/c/209f117b-debf-5170-ac4a-9bf5ac1efabe

Fernández, I. (2005). Construcción de escala aditiva tipo Likert. España. Retreived from http://www.mtas.es/insht/ntp/ntp_015.htm

Fernández, G. C. (2005). Qué significa la competitividdad en negocios internacionales. Retreived from http://www.alafec.unam.mx/mem/cuba/Negocios_internacionales/negint05.swf

Latruffe, L. (2010). Competitiveness, Productivity and Efficiency in the Agricultural and Agri-Food Sectors. OECD Food, Agriculture and Fisheries Papers (No. 30). OECD Publishing. http://dx.doi.org/10.1787/5km91nkdt6d6-en

Loría, E. (2007). Econometría con Aplicaciones. Universidad Autónoma de México. Editorial Pearson Educación, México.

López, M. F., \& Castrillón, J. (2007). In E. Gratuita (Ed.), Teoría Económica y algunas experiencias latinoamericanas relativas a la agroindustria. Retreived from http://www.eumed.net/libros/2007b/304/indice.htm

OECD. (2011). Fostering Productivity and Competitiveness in Agriculture. OECD publishing. http://dx.doi.org/10.1787/9789264166820-en

Padilla, B., Luz, R. R., Agustin, P. V. O., \& Reyes-Rivas, E. (2010). Competitiveness of Zacatecas (Mexico) Protected Agriculture: The Fresh Tomato Industry. International Food and Agribusiness Management Review, 13(1).

Pallares, F. (1988). Las políticas públicas: El sistema político en acción. Revista de estudios políticos (nueva época), 62, 141.

Porter, M. (2007). Competitive Strategy: Techniques for Analyzing Industries and Competitors. New York: Free Press.

Qineti, A., Rajcaniova, M., \& Matejkova, E. (2009), The competitiveness and comparative advantage of the Slovak and the EU agri-food trade with Russia and Ukraine. Agricultural Economics, 55(8), 375-383.

Ricardo, D. (1971). The principles of political economy and taxation (1817). Bltimore: Penguin.

Secretaría, de A., Ganadería, D. R., \& Pesca, A. (2009). Monitor agroeconómico 2009 del estado de Michoacán. Retreived from http://www.sagarpa.gob.mx/agronegocios/Estadisticas/Documents/MICHOACAN.pdf?Mob ile $=1 \&$ Source $=\% 2$ Fagronegocios $\% 2$ FEstadisticas $\% 2$ F_layouts $\% 2$ Fmobile $\% 2$ Fview.aspx $\% 3$ FList $\% 3$ Dea4 1 91c6-15b5-4625-afe9-be7e6cce2216\%26View\%3Df5c8d175-3fb9-49f2-86e6-c9db05b29bfb\%26Curren

Toming, K. (2007). The impact of EU accession on the export competitiveness of Estonian food processing 
industry. Post-Communist Economies, 19(2), 187-207. http://dx.doi.org/10.1080/14631370701312170

Wijnands, J., Bremmers, H., van der Meulen, B., \& Poppe, K. (2008), An economic and legal assessment of the EU food industry's competitiveness. Agribusiness, 24(4), 417-439. http://dx.doi.org/10.1002/agr.20167

\section{Copyrights}

Copyright for this article is retained by the author(s), with first publication rights granted to the journal.

This is an open-access article distributed under the terms and conditions of the Creative Commons Attribution license (http://creativecommons.org/licenses/by/3.0/). 